\title{
Classified Advertising and Meetings
}

\section{FELLOWSHIP IN OBSTETRIC ANESTHESIA}

The Department of Anesthesiology at Duke University Medical Center invites applications for a Fellowship in Obstetric Anesthesia for the academic year beginning July 1988 . Emphasis on clinical research and advanced clinical training in a tertiary center with approximately 3,000 deliveries per year including many high-risk consults and referrals. Opportunities to participate in NIH funded laboratory rescarch. Send inquiries to:

Elizabeth Bell, MD, Fellowship Director

Division of Women's Anesthesia

Department of Anesthesiology

Box 3094, Duke University Medical Center

Durham, NC 27710

Phone: (919) 681-3345.

\section{PAIN CLINIC IN TORONTO}

Anaesthetist wanted to provide sedation or light general anaesthesia to facilitate painful nerve blocks. No previous knowledge of pain work is necessary, but the opportunity is available for the successful applicant to learn and practice pain management with the help of the teaching program in a large well-organized clinic. Good income, hours negotiable. Please fax or mail your résumé to:

Rothbart Pain Management Clinic

Attention: B. Hann

Unit \#125, Box 129

North York, ON M2P 2E5

Phone: (416) 512-6407

Fax: (416) 512-6375

\section{CLASSIFIED ADVERTISING}

As a service to its readers, the Canadian Journal of Anaesthesia is pleased to accept suitable classified advertisements to announce positions availablc or wanted, meetings, postgraduate courses, or other events or items of interest to subscribers. Rates for classified advertising (for each insertion): $\$ 50$ for first 5 typeset lines, $\$ 5$ per typeset line (or partial line) thereafter. Minimum charge $\$ 50$.

7\% GST is added to Canadian orders. Copy must be received 8 weeks prior to the lst of the month of publication. Ad copy, subject to acceptance by the publisher, should be typed double-spaced and mailed or faxed to:

Canadian Journal of Anaesthesia

1 Eglinton Avenue East, Suite 208

Toronto, Ontario, Canada M4P 3 AI

Tel. (416) 480-0602, Fax (416) 480-0320

Specially priced display advertising space is

also available to non-commercial advertisers.

\section{OBSTETRIC ANAESTHESIA FELLOWSHIP}

The Department of Anaesthesia at the Ottawa General Hospital, University of Ottawa has an immediate opening for an Obstetric Anaesthesia Fellow up to June 30th, 1998. Please contact:

Dr. Dennis Reid, Department of Anaesthesia Ottawa General Hospital

501 Smyth Road

Ottawa, ON K1H 8L6

Phone: (613) 737-8187

Fax: (613) 737-8189

E-mail: dreid@aixl.uottawa.ca

\section{ACADEMIC ANAESTHETIST}

Dalhousie University and the Queen Elizabeth II Health Sciences Centre are seeking qualified anaes thetists to join the Department of Anaesthesia in the role of Clinician/Teacher or Clinician/ Researcher. Candidates for these positions should have completed a minimum of 12-24 months of postgraduate training in areas relative to teaching, clinical research or sub-specialty clinical practice. The successful candidate will possess good clinical skills and will demonstrate an ongoing interest in clinical research, and/or teaching. $\mathrm{He} /$ she should possess Certification by the Royal College of Physicians and Surgeons of Canada. This is a Clinical Continuing Track University position.

Halifax, the capital city of Nova Scotia, has excellent educational and recreational facilities. Dalhousie University is an Employment Equity/ Affirmative Action Employer

The University encourages applications from qualified aboriginal peoples, persons with disabilities, racially visible persons and women. In acordance with Canadian immigration requirements, this advertisement is directed to Canadian citizens and permanent residents. Please send applications with up-to-date $C V$ and 3 references' names to:

Dr. T.J. Coonan

Queen Elizabeth II Hcalth Sciences Centre

Victoria General Hospital Site

1278 Tower Road

Halifax, Nova Scotia B3H 2 Y9

\section{ACADEMIC ANAESTHETIST}

The Department of Anaesthesia at Sunnybrook Health Science Centre in Toronto is in need of full-time academic anaesthetists. Sunnybrook Health Science Centre is a fully affiliated reaching hospital with the University of Toronto. All types of anaesthetic practice with the exception of obstetrics and paedjatrics are available.

Academic activities at Sunnybrook Health Science Centre are concentrated in the following areas: 1) cell biology, mechanism of anaesthetic action, 2) critical care medicine, 3) trauma resuscitation and outcomes, 4) cardiovascular diseases, 5 ) acute and chronic pain management. Preference will be given to proven acadenic achievement in the above areas. All candidates must be eligible for registration with the College of Physicians and Surgeons of Ontario. Please contact:

Dr. Hugh Devitr, Head

Department of Anaesthesia

Sunnybrook Health Science Centrc

2075 Bayview Avenue, Suite C-818

North York, Ontario M4N 3 M5

Phone: (416) 480-4864

Fax: (416) 480-6039

E-mail: j.hugh_devitt@mail.magic.ca

\section{CLINICAL FELLOWSHIP POSITIONS}

The Department of Anaesthesia at Sunnybrook Health Science Centre is offering several oneyear clinical fellowship positions. We have openings commencing July lst, 1998.

A critical care fellowship position involves responsibility for a 30 -bed critical care unit. The unit is closed with the critical care medical staff providing patient care.

A fellowship in trauma resuscitation and anaesthesia is available. Sunnybrook Health Science Centre is a level one trauma referral centre for metropolitan Toronto and central Ontario. Approximately 700 acute trauma victims are admitted annually. Services to the trauma program provided by the Department of Anaesthesia include trauma team leading in resuscitation, trauma anaesthesia, critical care medicine and pain management.

A regional anaesthesia fellowship includes experience in eye, brachial plexus and neuroaxial blocks. Time can be made available for experience in acute and chronic pain management.

A Pain Fellowship position involves a multidisciplinary chronic pain management team which includes a diagnostic and therapeutic nerve block and chronic pain assessment clinic as well as an acute pain service. Experience in the evaluation and diagnosis of treatment of both acute and chronic pain is available.

A general clinical fellowship is available where experience in all areas of anaesthesia practice with the exception of paediatrics and obstetrics is available. Clinical fellows work in conjunction with the attending anaesthetic staff.

Non-clinical time ean be made available for research or educational activities. Candidates must be eligible for Canadian certification, American Board eligible or hold an equivalent qualification and be eligible for educational registration in the Province of Ontario. Interested applicants should send a curriculum vitae and two letters of reference to:

Dr. Hugh Devitt, Head Department of Anaesthesia Sunnybrook Health Science Centre 2075 Bayview Avenue, Suite C-818 North York, Ontario M4N 3M5 
xxxiv

\section{ANAESTHESIA POSITION}

The Department of Anaesthesia for the Sudbury General, Laurentian, and Memorial Hospitals has an immediate opening for a full-time anaesthetist Combined, the hospitals have over 700 acute care beds and provide a full range of surgical services including neuro, paediatric, cardiac, vascular, and thoracic surgery. The deparcment is also active in the Critical Care and Trauma units, and in the provision of acute and chronic pain services. Sudbury provides tertiary care referral services for Northeastern Ontario, with a catchment area of over 300,000 population.

Candidates must have attained specialty qualification by the Royal College of Physicians and Surgeons of Canada and be eligible for licensure in the province of Ontario. Interest in intensive care medicine would be an asset. A successful candidate will be joining the curren complement of 17 anaesthetists. This allows flexible holiday and professional leave and very reasonable call responsibilities.

Sudbury is the largest Northern Ontario communiry with a population of 100,000 . It offers a wide variety of cultural activities and in particular, is known for its outstanding outdoor recreational opportunities. Submit applications to:

Dr. Donald L. Wallis, Department of Anaesthesia Sudbury General Hospital

700 Paris Street

Sudbury, Ontario P3E 3B5

\section{CERTIFIED ANAESTHETIST}

Thunder Bay, Ontario - A certificd anaesthetist is required to join a group of eleven anaesthetists at Thunder Bay Regional Hospital on a fee-forservice basis. We provide tertiary anaesthetic care to all of Northwest Ontario for all surgical procedures except for open heart. This includes obstetrical anacsthesia, ICU, anaesthetic clinics and acute and chronic pain. Additionally we are committed to teaching Family Practice and GP Anaesthesia Residents. Preference will be given to applicants with ICU interest and skills.

Thunder Bay is a city of 120,000 on the shore of Lake Superior with superb winter and summer recreation including: skiing, boating, fishing and hunting. Send CV and 3 references to:

Dr. M. Scott, Chief of Anaesthesia

Thunder Bay Regional Hospital

$325 \mathrm{~S}$. Archibald Street

Thunder Bay, Ontario P7E 1G6

\section{CERTIFIED ANAESTHETIST}

Full-time anaesthetist required for a Northern Ontario city of 80,000 to join seven practising anaesthetists - fee-for-service remuneration. Full range of anaesthesia services, excluding cardiac and neurosurgery. Excellent facilities housed in two hospitals - I.C.U., C.C.U., epidural service, acute pain service. Ideal border community with outstanding recreational facilities. Please send $\mathrm{CV}$ and references to:

Dr. L. Hadley, Chief of Anaesthesia

Sault Area Hospitals

969 Queen Street East

Sault Ste. Marie, Ontario P6A 2C4

Phone: (705) 759-3604

Fax: (705) 759-3640

\section{Meetings - Canada}

\section{OMA/CAS Meeting}

September 13-14, 1997

London, Ontario

For information:

Dr. Richard J. Lee, Meeting Organiser

Department of Anaesthesia

London Health Sciences Centre

South Campus

375 South Street

London, ON N6A 4G5

Phone: (519) 667-6520

Fax: (519) 667-6708

E-mail: rlce@julian.uwo.ca

The Sesquicentennial of Anaesthesia

October 4-5, 1997

October 4: Our Changing Anaesthesia Practice

Ocbober 5: Anaestbesia ơ Co-existing Disease

Queen's University, Kingston, Ontario

For information:

Office of Contimuing Education

Faculty of Health Sciences

Queen's University

78 Barrie Street

Kingston, ON K7L 3N6

Phone: (613) 545-2540

Fax: (613) 545-6642

E-mail: grillsj@post.queensu.ca

Get the fax: 1-800-354-6058

WWw:

http://meds-ss10.meds.queensu.ca/medicine/cme

Paediatric Anaesthesia Conference

The Hospital for Sick Children

November 7-9, 1997

Toronto, Ontario

For information

Paediatric Anaesthesia Conference

The Hospital for Sick Children

555 University Avenue

Toronto, ON M5G 1 X8

Phone: (416) 813-7445

Fax: (416) 813-7543

Obstetrical Anaesthesia Update

Anaesthetic Practice '97

November 20-23, 1997

Royal York Hotel

Toronto, $\mathrm{ON}$

\section{For information:}

Ms. Jenny Powell

University of Toronto

Room 132, Fitzgerald Building

150 College Street

Toronto, ON M5S 1A8

Phone: (416) 323-6008

Fax: (416) 323-6307

E-mail: powell@ftn.net
Canadian Anaesthetists' Society

55th Annual Meeting

June 12-16, 1998

Westin Harbour Castle, Toronto, Ontario

For information:

Ms. Annette Schilz, Meeting Coordinator

Canadian Anaesthetists' Society

1 Eglinton Ave. East, Suite 208

Toronto, ON M4P 3Al

Phone: (416) 480-0602

Fax: (416) 480-0320

E-mail: cas@multinet.net

WWW: http://www.cas.ca

12th World Congress of Anaesthesiologist June 49,2000

Palais des Congrès, Montréal, Québec

For information:

Canadian Anaesthetists' Society

1 Eglinton Avenue East, Suite 208

Toronto, ON M4P $3 \mathrm{Al}$

Phone: (416) 480-0602

Fax: (416) 480-0320

WWW: http://www.cas.ca

\section{Other Meetings}

Society for Pediatric Anesthesia

11 th Annual Meeting

October 17, 1997

San Diego, California

For information:

Society for Pediatric Anesthesia

P.O. Box 11086

Richmond, VA 23230-1086

Phone: (804) 282-9780

Fax: (804) 282-0090

E-mail: 75112.2053@compuserve.com

American Society of Anacsthesiologists

(ASA) Annual Meeting

October 18-22, 1997

San Diego, California

For information:

Frank Connell

American Society of Anaesthesiologists

$520 \mathrm{~N}$ Northwest Highway

Park Ridge, IL 60068-2571

Phone: (847) 825-5586

Fax: (847) 825-1692

72nd Clinical and Scientific Congress of the International Anesthesia Research Society (IARS)

March 7-11, 1998

Marriot's Orlando World Center, Florida

For information:

IARS

2 Summit Park Drivc, Suite 140

Cleveland, $\mathrm{OH}$ 44131-2553

Phone: (216) 642-1124

Fax: (216) 642-1127 